\title{
New Global Reality And Challenges To Regional Growth
}

\author{
E.D. Dagbayev, \\ Buryat State University, \\ Ulan-Ude, Russia \\ edagbaev@mail.ru, \\ T.B. Badmatsyrenov \\ Buryat State University \\ Ulan-Ude, Russia \\ ndagbaeva@mail.ru
}

\author{
N.Zh. Dagbayeva \\ Buryat State University \\ Ulan-Ude, Russia \\ ndagbaeva@mail.ru \\ P.P. Dashinimayeva \\ Buryat State University \\ Ulan-Ude, Russial \\ ndagbaeva@mail.ru
}

\begin{abstract}
The article singles out most important factors that, in terms of the new global reality, become the growth and development points for a particular region, i.e. the Republic of Buryatia. The factors coincide with the trends and directions, in which both Russia and the rest of the world develop today. The main focus is significant projects that in the context of the current globalization activities might challenge Buryatia's collaboration with other countries within the Russia-ChinaMongolia cooperation framework. In particular, it is about taking advantage of the territory location in the zone of largescale Russian communication junctions; the contiguity to the Russian borders on the transit routes to Europe, as well as the main directions and prospects of cross-border cooperation between the neighboring and related countries. The authors note that economic, social and political regional development largely depends on participation in international projects, and development of small and medium-size businesses. The ChinaMongolia-Russia economic corridor may develop the Republic of Buryatia in economic terms so that it becomes one of the crucial regions of the country. Implementation of Baikal Special Economic Zone project is equally important to boost the region. Another factor of the regional growth is political consolidation in the region as well, transparency of the regional community to the global information and financial flows.
\end{abstract}

Keywords—growth points, regional development, international challenges and projects

\section{INTRODUCTION}

In terms of social and economic development and their potential, Russian regions differ significantly from one another, but they all have their own points that might promote growth. But to identify the growth areas that can actually snap into action in the Republic of Buryatia, it is necessary to do a thorough analysis.

According to Yu. N. Gladkov and A. I. Chistobaev, such growth areas for Buryatia are contiguity of maritime transboundary routes, of the Russian border on the transit routes to Europe, and location in the zone of Russian largescale communication junctions [1].

It is obvious enough, the Republic of Buryatia cannot be included into highly developed economic regions of Russia. However, its potential is rather transparent [2].

\section{PROBLEM STATEMENT}

Let us consider what these growth areas [3] with regard to the Republic of Buryatia are, and how they might be activated.

Clearly, the first factor - being remote from the sea routes - reduces the possibility for a rapid development. However, the second one and, today, the third factor too start to change the situation. Now, people are looking for a way out of the crisis within the region caused by both objective and subjective reasons. In this case, the decisive role belongs to the competent regional economic policy, which cannot organically be closed within the state institutions activities. This is the overall activity of commercial structures, non-profit public organizations, transnational corporations, and market infrastructure.

The following factors can be regarded as the decisive point or the accelerator of a new regional economic policy implementation: 1) speeding-up of scientific and technological progress promotion, thus providing an innovation potential increase; 2) regionalization, or the process of gaining definitely expressed territorial interests, and, on their basis, formation of regional identity [4].

However, regional development cannot be based on the "bare" economy, that is, be connected only with regional economic policy. A number of regional policy components are needed to be promoted: internal and external economic, social, cultural and others. There is one more factor to provide a strong regional policy - proper political conditions, meaning the political unanimity in the region and the economic space 
unity in the country, and synchronicity of federal and regional government bodies' activities [5].

In the sense of more dynamic regional development, regionalization means independence of regions on the international arena, and hence, their ability to derive economic benefits from their geographical location. Here the most important thing is not to regard ourselves as an internal periphery. Such political factor as the political and business elite quality also acquires great significance, along with geographical and socio-economic factors [7].

Indeed, there is a primary advantage in the border regions, but, paradoxically, most of border areas in our country are less developed than inland ones. This is due to the economy structure and content inherited from the USSR. On the contrary, a cross-border cooperation in the Russian NorthWest and the states located in the Baltic zone (before the conflict in 2014-2017) have shown quite a high efficiency of the projects implemented up to a proper economic scheme [8]. As a result, such powerful structures as the Council of the Baltic Sea States, the Council of the Barents / Euro-Arctic Region, the EU project "Northern Dimension", transboundary Euro-regions "Baltica" and "Saool" were formed.

\section{RESEARCH QUESTIONS}

It is clear that the new global project "Silk Road" initiated by China became a significant chance as a "growth area" for Buryatia. One should remind that in 2013, Chinese President Xi Jinping announced the launch of a large-scale project "Silk Road" and called on all countries to join it. On May 15, 2017 in Beijing, the forum "One Zone - One Way" took place. Many heads and representatives of the business community from Asian and European countries came to participate in it. This forum really demonstrated a high level of international cooperation within the "Zone and Way" (the Economic zone of the Silk Road and the Sea Silk Road of the XXI century).

Obviously, the joint construction of "Zone and Way" will allow one to better use the advantages of each participating country and turn the economic complementarity into new impulses for development not only for China, but for the world economy [9]. Although, it is likely that China will become the main beneficiary of this project.

China proposed to initiate "Economic zone of the Silk Road" (EBSR) as early as 2013. And in 2016, China's total trade volume with countries along the Silk Road already amounted to $\$ 954$ billion, or $25.7 \%$ of the global trade volume.

Russian President Vladimir Putin confirmed his desire to participate actively in a large-scale Chinese project. He proposed to combine the various integration processes taking place in Europe and Asia, on the basis of the universal principles and norms of the WTO. Chinese-Russian cooperation in this field began on May 2015. This day the joint statement on cooperation in combining the Economic zone of the Silk Road and the Eurasian Economic Union was signed. Chairman Xi Jinping and President Vladimir Putin discussed cooperation details many times, including during SCO and BRICS summits in Ufa.
At present, China and Russia are working on the Greater Eurasian partnership conception [10]. This conception implies the construction of a high-speed Moscow-Beijing highway and the gas main "Siberian Power". The project "Silk Road" can include the capabilities of BAM and Transsib, as well as the capacity of the Far Eastern port. Russia is promoting projects related to transport corridors operating in Russia. At the same time, even if the Silk Road project will not be very profitable for Russia, then, probably, Russia will not be a loser anyway. Now the Chinese share in the foreign trade turnover of Russia is $14 \%$.

Terms for the goods transport from China to Europe can be reduced from the current 45-60 days by sea to 10-13 days by land. It will be an obvious benefit for China. In this case, Chinese goods are significantly cheaper; the position of their goods becomes much more durable in all Asian and European markets, and supplies are optimized. Of course, new markets for the goods sale are emerging, including in Africa and the Middle East.

China wants to involve into economic and technological fields new social groups, including peasants. To provide these industries with work for decades to come, they would like to forward Chinese railway and construction companies far beyond their borders. By the end of the decade, the total length of the high-speed highways network in China should reach $30,000 \mathrm{~km}$. This industry has invested tremendous resources, providing amazing pace of the high-speed trails construction. The Chinese leadership understands that quite soon the Chinese high-speed network will reach the limit of "saturation" and economic profitability, even with a huge population and territory. China is ready to invest up to 300 billion rubles in the construction of the Moscow-Kazan highspeed railroad (HSRR). The first Russian fully-fledged HSRR with a length of $770 \mathrm{~km}$ should shorten the journey time between Moscow and Kazan from 11.5 to 3.5 hours. The highway is supposed to be built using Chinese technologies and loans from Chinese banks. And mainly Russian companies will supply materials and rolling stock.

As for Russia, it can become a full-fledged "Eurasian bridge" between Eastern and Western countries, by integrating into the Trans-Eurasian trade routes, thereby consolidating its geopolitical position. The construction of roads, bridges, etc., that is of the transport infrastructure, will become cheaper, because the payback of capital investments decreases. Cooperation with China allows for the full development of the Asian regions of Russia, the ones that lag behind European countries [11].

Hence in the current international conditions, the key task of the Republic of Buryatia is to get involved in the Silk Road project. Even if the main branch of "Silk Road" does not pass through Buryatia, it is needed to develop logistics in order to revive on its basis its economic ties and trade with China and Mongolia.

Another important factor of the "growth area" is Mongolia. Despite the eternal neighborhood with Mongolia, Buryatia had not previously been able to derive economic benefits from this factor. In 2014-2016, it was precisely the possibility of visafree visits by both states' citizens that allowed in many ways 
to "save" the situation in Buryatia. The constant flow of Mongolian shopping tourists brought huge funds to the budgets of trade enterprises and the republic as a whole, as reported by the republic head V. V. Nagovitsyn at the meeting with V. Putin in 2015. In general, on the basis of common historical and territorial links, the close economic ties between Mongolia and Buryatia, can bring tangible benefits to our region.

The same year, Mongolian President Tsakhiaghiin Elbegdorj presented an ambitious project called The Steppe Road to his Russian counterpart Vladimir Putin. The project is able to completely reform the Russian-Chinese traffic environment. It has not been accepted yet, but it has a high potential in terms of building a whole complex of carriers through Mongolia.

Firstly, the Steppe Road includes a railway reconstruction to speed up and increase the capacity of trains. The project has already got off the ground: Russian Railways and the Ministry of Road and Transport Development of Mongolia have signed an agreement. The further plan concerns another railway and electrification.

Secondly, the project aims to build a multilane highway for heavy vehicles.

Thirdly, it considers lying high-voltage power lines between China and hydroelectric dams of Angara river.

Fourthly, it aims to install an oil and gas pipeline. Taking into account the absence of mountain groups, marshy areas or low risks of inundations, the idea is an apparent advantage of the Steppe road. Built long ago, the railroad line has approved itself as a stable transport system that is merely exposed to extreme weather conditions.

The line through the territory of Mongolia will make it possible to reduce the cost of energy delivery to densely populated industrial areas around the Chinese capital. Moreover, the burden costs of Chinese goods delivery from Beijing to Ulan-Ude will be cut down.

As said in newspapers, a special procedure for goods clearance may be introduced, so there will be no need to reinspect them at the border. As they arrive in Mongolia, vehicles and containers will be sealed and screened at their exit from the country.

The Chinese government has approved the Steppe road project. The logistics potential of Buryatia enables the republic to participate in the Steppe road [12]. In general, the road construction in the area of Chinese-Russian border points of Manchuria and Erehnkhot (Erlian) accelerated, and primarily aims to make it easier for tourists who go by road to travel to Mongolia, Buryatia and other East Siberian regions.

By 2020, about 10 thousand kilometers of main roads are expected to be completed here in the north of China. The roads are planned to be engaged in the Steppe Road project, upon which the Mongolian authorities and the Chinese government agreed. For now, Russia does not explicitly support the project. However, the so-called China-MongoliaRussia Economic Corridor initiative has already been set in motion.
In recent years, our region's part in geopolitical interactions between major powers and in regional international security has been growing important.

In a historical retrospective, a well-known Russian expert in Mongolian studies, A. S. Zheleznyakov emphasizes an important moment: the fully coincided interests of strategic partners manifested themselves right before, during, and after the end of the World War II. Then, Mongolia played an inestimably important role as a reliable ally and a Far East rear for the USSR. In its turn, as a great victorious power, the Soviet Union helped its backer Mongolia liberate from China's suzerainty and become an independent state and join the UN in 1961. With Soviet-Mongolian armies battered the Japanese militarists in 1939 nearby Khalkhyn Gol River, the Soviet Union enabled a reposition of its large forces from the Far East and Transbaikalia to the crucial points of the Western front [13].

Up to this historical route, today, Russia evidently has important preferences and major unresolved problems related to Mongolia.

Being not only Mongolia's patron anymore, as the Russian Empire and the USSR used to be in their days, modern Russia, while having received the status of one of Mongolia's three strategic partners, has not yet fully determined its new role. Currently, its playing a passive role in the partnership has virtually no effect on the formation of a new alignment of strategic forces in Mongolia and nearby territories.

Meanwhile, in case of a favorable geopolitical situation of regional security, there are huge opportunities to activate an economic and political potential. For example, speaking about relationships with North Korea, the region is aware of the possibilities and initiatives that Mongolia has. It is obvious that DPRK trusts Mongolia that - for many minds, unexpectedly - started to play its particular part in the process of North and South Korea Reconciliation. The informal ChinaMongolia bundle could potentially get the Korean problem off the ground. Interestingly, Buryatia also contributed to the meeting of Kim Jong-il and Dmitry Medvedev in 2011, providing a platform for their meeting in Sosnovy Bor near Ulan-Ude.

Nowadays, considering tough relations with its southern neighbors, China is obviously striving to create a certain counterbalance in geopolitical aspirations in its north. The media called these attempts as creating an alternative "Mongolian case".

Given that it has close cultural, social and economic ties with Mongolia, Buryatia could potentially contribute to maintaining the balance of power. This requires Buryatia to be considered as an important partner having a system with stable policy and economy.

The area studies experts talked a lot - especially in the early 2000s - about the fact that, for example, the Baltic region enabled a level of security that it has never had in its entire history. At the same time, the Baltic region represents a unique zone where different forms and levels of provided security mix. Here, we can see various "security identities" 
collide; but, following the common interests of geopolitical actors, each of them levels off [14].

Today, the China-Mongolia-Russia economic corridor may develop a similar setting. As for Russia, the Republic of Buryatia may become one of the crucial regions participating in the configuration. Either way, the macro-region of Central Asia (not to be confused with the modern name of Central Asia) has a number of specific features emphasizing how significant it is in terms of security.

In this context, development of the Baikal Special Economic Zone (SEZ) is equally important [15].

The federal government has provided Buryatia with six powers, which virtually constitute all aspects of work with its residents. (The signing ceremony was held in St. Petersburg during the St. Petersburg Economic Forum.) The zone performance assessment will be based on the outcomes of 2021. The land management has been transferred to the region as well, and, for this purpose, the "second stage" lands will be established - Goryachinsk, Bezymyanny, and Mount Bychya. The economic focus on tourism in Buryatia and the Baikal factor impact the strengthening of international cooperation in the economic field [16]. So, the Special Economic Zone project does boost the regional development.

\section{PURPOSE OF THE STUdy AND RESEARCH METHOdS}

We are to analyze how regionalization factors become growth areas of a given region considering the current difficult international situation. In this regard, we identify opinions and viewpoints on the state and the prospects of the country's economic development.

To complete the task, we used an event analysis - a technique that aims to process the information that shows who is speaking or doing something, what they are saying or doing, about whom and when they are saying or doing that. In this case, the data is processed according to the following parameters: the initiating subject (who?), the plot (what?), the object (about whom?), the date of the event (when?).

The method enables us to see the coincidence of the interests required in planning of the economic boost to establish the cause-effect relationship between these variables.

\section{CONCLUSION}

The Republic of Buryatia is now in a position when it has potential growth areas that may or may not be leveraged. The fact that Russian President Vladimir Putin replaced the previous head of the Republic, Vyacheslav V. Nagovitsyn, with a "young technocrat" deputy, Russian Transport Minister Alexey S. Tsydenov, who gained 87 percent of the vote during the direct election, may contribute to success. People liked that the Republic was going to be led by a young person with an expertise in collaboration between federal structures, with the experience in public administration, and most importantly with a political support by Vladimir Putin and the Russian government. That is why the people in Buryatia have high hopes for him: they think he is able to meet the challenges discussed herein.
Therefore, in the current international situation, the political consolidation in the region becomes another factor of the regional growth.

Collectively, with all the above-mentioned factors considered, everything results in creating a regional cogovernance model that implies new actors' introduction into management (entrepreneurs organizations, employers unions, research institutions, international organizations, non-profit organizations).

Inclusion into global strategies will require the regional community to be transparent and open to the global information and financial flows, and concurrent development of a local cultural authenticity. In this case, Buryatia may develop through building up its potential by playing its part in the international cooperation with different countries.

\section{Acknowledgment}

The article was written as part of government order №28.6725.2017/БЧ of the Ministry of Education and Science of the Russian Federation, "The Regional Community in Russia-Mongolia-China Transboundedness - the Global and Local Dimensions".

\section{References}

[1] Yu.N Gladkii., A.I. Chistobaev "Regionovedenie": uchebnik [Regional Studies: Students’ Book]. Moscow: Gardariki, 2002, p. 384.

[2] Ts.N.Yandanova, V.G. Irildeev, "Economika Respubliki Buryatia v territorial'nom aspekte" [Economy of the Republic of Buryariya in Terms of Territory]. BSU Vestnik. Philosophy, Pedagogics and Philology, vol. 2(1). pp. 70-77, 2015.

[3] L.N. Ivanova, G.A. Tyorskaya, "Tochki rosta b draivery rosta: k voprosu o soderzhanii ponyatiya" [Points and Drivers of Growth: Issue of the Notion Content], Journal of institutional studies, vol. 2, pp. 120-133. 2015.

[4] V. Knyaginin, P. Schedrovitskii "Na poroge novoi regionalizatsii Rossii” [On the Brink of a New Regionalization of Russia], In: Rossiya mezhdu vchera I segodnya [Russia Between Yesterday and Current Time] V. Preobrazhenskii, D. Dragunskii, Eds. Moscow, 2003, pp. 84107.

[5] E.D. Dagbaev, "Regiony I novaya vostochnaya politika Rossii" [Regions and New Eastern Politics of Russia], Polis. Political Researches, vol.1, pp. 151-157, 2015.

[6] N. Zh. Dagbaeva, "Iz opyta luchschikh praktik desyatiletiya obrazovaniya $\mathrm{v}$ interesakh ustoichivogo razvitiya $\mathrm{v}$ rossiiskikh regionakh" $\left[10^{\text {th }}\right.$ Jubilee of Education in Favor of Sustainable Development in Russian Regions. Excerpts from the Best Practices], Vestnik of Buryat State University, Pedagogics, vol. 1(1), pp. 3-7, 2014.

[7] See: "Regional'naya integratsiya v sovremennom mire i dinamika makropoliticheskoi identichnosti" [Regional Integration in Modern World and Macropolitical Identity Dynamics], Politicheskaya identichnost' i politika identichnosti [Political Identity and Policy of Identity]. 2 Identities, and Social and Political Changes in XXI Century / I.S. Semenenko, Ed. Moscow: ROSSPEN, 2012.

[8] I.M. Busygina, "Strukturnaya politika i rol' regionov v Yevropeiskom Soyuze" [Structural Politics and Role of Regions in EU], in: Politics and Economy in Terms of Regions, Studia politika, vol. 3, Irkutsk, 2003.

[9] S.G. Luzyanin, "Pogloscheniye, sopryazheniye ili konflikt? ShOS, kitaiskii proyekt Shyolkovogo Puti i YeAES: variant vzaimodeistviya v Yevrazii" [Absorption, Conjugacy or Conflict? SCO, Chinese Project of Silk Road and EEU: Eurasian Cooperation Variant], Moscow: Institute for Far East Studies, Russian Academy of Sciences, 2016, 61 p. 
[10] S.G. Luzyanin ShOS, “Odin poyas, odin put', Rossiiskaya proyektsiya i problemy sopryazheniya" [SCO. "One Zone, one Road". Russian Perspective and Conjugacy Problems.], In: China in World and Regional Politics, History and Modern Time, Moscow, pp. 3-9. 2017.

[11] B.V. Bazarov et al. "Problemniye regiony resursnogo tipa: Aziatskaya chast' Rossii" [Resource-Related Regions with Challenges: Asian Part of Russia], In: Integration Projects, Russian Academy of Sciences, Siberian Department, 4. Novosibirsk, 385 p., 2005.

[12] L.Ye. Yangutov, "III Mezhdunarodnyi forum assotsiatsii ekspertnykh tsentrov Kitaya, Mongolii i Rossii "Ekonomicheskii koridor KitaiMongoliya-Rossiya: Dorozhnaya Karta" $\left[3^{\text {rd }}\right.$ International Forum of Expert Centres Association of China, Mongolia and Russia "Economic Corridor China-Mongolia-Russia: Roadmap Timeline], In: Far East Problems, vol. 6, pp. 166-172, 2017.

[13] "Mesto Rossii i Mongolii v sovremennoj regional'noj konfiguratsii", [Place of Russia and Mongolia in Modern Regional Aspect] A.V. Glazova, Ed., Moscow: Russian Institute for Strategic Studies, 2012, pp. 58-64.

[14] N.M. "Mezhevitch Rossiya i gosudarstva Pribaltiki: nekotoriye itogi i perspektivy mezhdunarodnykh otnoshenii”, [Russia and Baltic States:
Preliminary Summary and Prospects of International Relations], Baltic Region, vol. 2 (24), pp. 7-18, 2015.

[15] N.G. Sannikova, "East Siberian Tourism And Recreation Special Economic Zone: The Historical Experience", In Irkutsk HistoricalEconomic Yearbook, Irkutsk: Baikal State University, pp. 344-348, 2013.

[16] M. Vrublevskaya, "Vtoroye Dykhaniye Baikalskoi Gavani” [Revival of "Baikal Gavan" "], In: InformPolis, $18^{\text {th }}$ March 2017. 